\title{
Experimental investigation of the pressure loss through a double skin facade by using perforated plates
}

\author{
Tahsin Başaran*, Tuğba İnan \\ Department of Architecture, Izmir Institute of Technology, 35430 Urla, Izmir, Turkey
}

\section{A R T I C L E I N F O}

\section{Article history:}

Received 1 July 2016

Received in revised form 13 October 2016

Accepted 14 October 2016

Available online 14 October 2016

\section{Keywords:}

Double skin facade

Perforated plate

Pressure drop

Cavity

\begin{abstract}
A B S T R A C T
The aim of this study is to analyze the effect of perforated elements on pressure drop in a double skin facade cavity. This cavity separates the exterior and interior space as thermally controllable. The temperatures of the surfaces facing cavity with exterior and interior spaces have been determined experimentally under different airflow conditions. Two distinct perforated plates having different circular hole dimensions are positioned in the double skin facade cavity in order to create a pressure drop in the cavity. Pressure drops and temperature distributions in the cavity have been examined based on experimental measurements. The results show the surface and air temperature distributions in the cavity, the pressure drops under three different air flow rates and two different perforated plates. The dependence of the dimensionless pressure drop coefficient, Euler versus Reynolds numbers is investigated experimentally for different geometric characteristic of the perforated plates. So, Eu numbers independency after 30,000 of the Re numbers approximately is shown graphically. Evaluating the pressure loss in the DSF's cavity under usage of different type of pressure drop elements is essential for ventilating the cavity and choosing the fan capacity in the DSF applications.
\end{abstract}

(c) 2016 Elsevier B.V. All rights reserved.

\section{Introduction}

Double skin facade (DSF) is rapidly becoming a common design feature in architecture. These systems are nowadays accepted by many architects and developers in the world. The basic presumption behind this global proliferation is that, considering the climatic conditions, the double-skin glass facades can provide the advantages of energy gaining and controlled ventilation. DSF is an envelope construction consisting of two transparent facades separated by a cavity. DSF acting as a new second building envelope usually comprises of an external skin and an internal skin which is made of glazed or partially glazed material. While the external glass surface usually consists of a single transparent glass, the internal glass surface is usually double glazing; it consists of low-e or solar control glasses. These skins separated from each other by an air cavity. The width of this air cavity can vary from $0.2 \mathrm{~m}$ to more than $2 \mathrm{~m}$. This cavity behaves like a thermal buffer zone; it can be ventilated by natural or mechanical. The flow and energy analysis of DSF are evaluated on various studies in the literature. The

\footnotetext{
* Corresponding author.

E-mail addresses: tahsinbasaran@iyte.edu.tr, tahsin.basaran@deu.edu.tr (T. Başaran)
}

latest reviews about DSF's studies are published by Pomponi et al. [1], Ghaffarianhoseini et al. [2], Zhang et al. [3]. Although there are many studies on DSF, the number of the experimental studies under the laboratuary condition is limited [4-10]. Most of the experimental studies are based on the observation of the data gathered from the existing double skin facade buildings. As it is almost impossible to control the environmental factors which affect the building outside, depending on the fact that the behaviours of the building users cannot be foreseen, the comparison of the measurement data taken from a real building and the results of the simulations does not give reliable results for the wide range of applications. In the laboratory environment where the environmental factors can be controlled, the data taken from the experimental setup allows to obtain more flexible, reliable and the wide range data.

Solar shading elements are protected from adverse weather conditions by placing them in the cavity. These elements remove undesirable sun rays from the interior facade by reflecting or absorbing a portion of them. They have a positive effect on the building's cooling load. The shading devices in a DSF can be usually located in the cavity close to the external facade because of providing more convenient working area for maintenance and repair. Different kinds of plants are also used as a shading element in the cavities. They provide reduction of temperature and cooling load. There are many studies related to the energy and flow analysis in 
Table 1

Pressure drop elements in the DSF cavity on the literature.

\begin{tabular}{|c|c|c|c|c|}
\hline$\neq$ & $\Delta \mathrm{P}$ element & Tools \& models & Parameters & Findings \\
\hline 4 & Plant and blind & $\begin{array}{l}\text { experimental } \\
\text { simulation } \\
\text { program } \\
\text { forced } \\
\text { unsteady }\end{array}$ & $\begin{array}{l}\text { no shading } \\
\text { plants } \\
\text { blinds } \\
\text { @laboratory }\end{array}$ & $\begin{array}{l}\text { Plants provided comfortable indoor climate and energy } \\
\text { savings. } \\
\text { The positive influence of plants on the cooling system was } \\
\text { obtained. } \\
\text { Plants were more effective shading system than blinds. } \\
\text { Temperature of each surfaces in a DSF with plant was } \\
\text { generally much lower than blind. }\end{array}$ \\
\hline 5 & Shading device & $\begin{array}{l}\text { experimental } \\
\text { simulation } \\
\text { program } \\
\text { forced/ } \\
\text { natural } \\
\text { unsteady }\end{array}$ & $\begin{array}{l}\text { comparison of DSF with single skin } \\
\text { facade } \\
\text { external/internal shading } \\
\text { different ventilation strategy } \\
\text { @Delft, Netherlands } \\
\text { \&laboratory }\end{array}$ & $\begin{array}{l}\text { Energy performance comparison of different facade } \\
\text { applications. } \\
\text { Annual cost was analyzed and compared each other } \\
\text { considering facade, HVAC and energy. } \\
\text { DSF with HVAC installation was found to be more } \\
\text { economical solution. }\end{array}$ \\
\hline 8 & Venetian blind & $\begin{array}{l}\text { experimental } \\
\text { forced/ } \\
\text { natural } \\
\text { steady }\end{array}$ & $\begin{array}{l}\text { variation of airflow } \\
\text { different angle of shading device } \\
\text { @laboratory }\end{array}$ & $\begin{array}{l}\text { Experimental data set was obtained. } \\
\text { Air and surface temperatures in DSF were affected by the } \\
\text { venetian blind angle and airflow rate. }\end{array}$ \\
\hline 9 & Shading device & $\begin{array}{l}\text { experimental } \\
\text { zonal model } \\
\text { forced } \\
\text { steady }\end{array}$ & $\begin{array}{l}\text { different airflow rates } \\
\text { different angles of the solar shading } \\
\text { devices } \\
\text { @laboratory }\end{array}$ & $\begin{array}{l}\text { Temperature of the exterior glazing increased relatively } \\
\text { small and interior temperature decreased when the tilt } \\
\text { angles increased. } \\
\text { Temperature values in the cavity decreased when the } \\
\text { flowrate increased. }\end{array}$ \\
\hline 11 & Venetian blind & $\begin{array}{l}\text { CFD } \\
\text { forced } \\
\text { porous } \\
\text { steady }\end{array}$ & $\begin{array}{l}\text { slat tilt angle } \\
\text { blind position } \\
\text { air outlet position } \\
\text { 2D/3D comparison }\end{array}$ & $\begin{array}{l}\text { The distance between the blind and outdoor glass had a } \\
\text { significant effect on the velocity profiles inside the cavity. } \\
\text { Porous media approximation for blind simplified the } \\
\text { model and provided results which agreed with real } \\
\text { venetian model. }\end{array}$ \\
\hline 12 & Roller blind & $\begin{array}{l}\text { CFD } \\
\text { simulation } \\
\text { program } \\
\text { natural } \\
\text { steady }\end{array}$ & $\begin{array}{l}\text { cavity geometries } \\
\text { shading device type } \\
\text { different solar radiation }\end{array}$ & $\begin{array}{l}\text { Correlations were performed for DSFs with } \\
\text { buoyancy-driven airflow. } \\
\text { Correlations were developed for airflow rate in cavity } \\
\text { versus average and peak cavity-outdoor air temperature } \\
\text { difference. } \\
\text { Air temperature difference versus pressure difference } \\
\text { between cavity and outside. }\end{array}$ \\
\hline 13 & Venetian blind & $\begin{array}{l}\text { CFD } \\
\text { zonal model } \\
\text { natural } \\
\text { unsteady }\end{array}$ & @Beijing, China weather data & $\begin{array}{l}\text { Two gaps divided by blind had asymmetric flow and } \\
\text { different temperature distribution. } \\
\text { Good agreement was obtained between the simulation } \\
\text { and experiment. }\end{array}$ \\
\hline 14 & Venetian blind & $\begin{array}{l}\text { experimental } \\
\text { zonal model } \\
\text { forced/ } \\
\text { natural } \\
\text { unsteady }\end{array}$ & $\begin{array}{l}\text { cavity height } \\
\text { mass flow rate } \\
\text { venetian blind position } \\
\text { inlet-outlet temp. difference } \\
\text { @Torino, Italy }\end{array}$ & $\begin{array}{l}\text { Inlet-outlet temperature difference increased with DSF } \\
\text { height and installing venetian blinds in the cavity. } \\
\text { The influence of each parameter was more apparent in } \\
\text { daytime. }\end{array}$ \\
\hline 15 & Plant & $\begin{array}{l}\text { experimental } \\
\text { forced } \\
\text { unsteady }\end{array}$ & $\begin{array}{l}\text { different plant density @Shanghai, } \\
\text { China }\end{array}$ & $\begin{array}{l}\text { Solar heat gain coefficients (SHGC) of DSF were obtained } \\
\text { for different plant density. } \\
\text { SHGC and cavity temperature decreased with the increase } \\
\text { of plant density which did not solve overheating in the } \\
\text { cavity. }\end{array}$ \\
\hline 16 & Venetian blind & $\begin{array}{l}\text { CFD } \\
\text { experimental } \\
\text { natural } \\
\text { porous } \\
\text { steady }\end{array}$ & $\begin{array}{l}\text { outdoor wind speed } \\
\text { different solar radiation } \\
\text { two different CFD models } \\
\text { @Tsinghua University, China }\end{array}$ & $\begin{array}{l}\text { The porous media model showed good computational } \\
\text { accuracy. It also significantly reduced the mesh number } \\
\text { and computing time. } \\
\text { Effective natural vent. occurred in each case. } \\
\text { Pressure drop versus air velocity through blind was } \\
\text { obtained. }\end{array}$ \\
\hline 17 & Venetian blind & $\begin{array}{l}\text { CFD } \\
\text { natural } \\
\text { steady }\end{array}$ & $\begin{array}{l}\text { blind tilt angles and positions } \\
\text { different model strategy considering } \\
\text { with internal and external } \\
\text { environment conditions }\end{array}$ & $\begin{array}{l}\text { When blinds positioned about one third from the external } \\
\text { facade, optimum energy saving was provided. } \\
\text { Blind tilt angle, } 30^{\circ} \text {, decreased incoming solar energy to } \\
\text { indoor space by about } 85 \% \text {. }\end{array}$ \\
\hline 18 & Plant & $\begin{array}{l}\text { simulation } \\
\text { program } \\
\text { forced } \\
\text { unsteady }\end{array}$ & $\begin{array}{l}\text { two different simulation models } \\
\text { @Salta, Argentine weather data }\end{array}$ & $\begin{array}{l}\text { Heat gain and heat loss were reduced to } 30 \% \text { and } 63 \% \text {, } \\
\text { respectively by using plants. }\end{array}$ \\
\hline 19 & Venetian blind & $\begin{array}{l}\text { experimental } \\
\text { natural } \\
\text { steady }\end{array}$ & $\begin{array}{l}\text { tree different slat angles } \\
\text { different solar radiation } \\
\text { different wind velocity } \\
\text { @Laboratory }\end{array}$ & $\begin{array}{l}\text { Temperature profiles were quite different between the } \\
\text { cases with the slats in the closed and maximum open } \\
\text { positions. } \\
\text { Wind pressure coefficient for different direction } \\
\text { considering upper and lower parts. } \\
\text { Buoyancy and wind driven pressure effect were compared } \\
\text { each other for different situations. }\end{array}$ \\
\hline
\end{tabular}

the cavity with shading elements; organic or inorganic. These studies are given in Table 1 based on the pressure drop elements of the cavity $[4,5,8,9,11-19]$.
Majority of analyzes mentioned above focused on the energy performance-oriented examinations and numerical flow analysis supported by experimental studies. On the other hand, pressure drop in the cavity were defined by using outside wind pressure 
effect which were measured experimentally in the references numbered $11,12,16,19$. There are some studies which are focused to the outside wind velocity for determining the pressure distribution through the outside of the DSF in the literature [20-22]. Wind effect was used for preventing overheating inside of the DSF cavity in Nasrollahi, Salehi's study [20]. Different openings at the lower side and different geometric forms at the upper side of the cavity were investigated under different wind pressure effect to obtain sufficient ventilation in hot, dry climates. Choi et al. [21] defined pressure difference in the cavity based on the stack and wind effects. Wind pressure coefficients considering different wind angle were obtained by using experimental and numerical tools for three different DSF applications in Loua et al. [22]'s experimental study. They found that internal and external pressures depended on the geometric configurations with wind incidence. Different from the previous studies, this study focused the pressure drop in the DSF' cavity created by using perforated plates which were symbolized plants, blinds or walking corridor usage in the real situation. Perforated plates are widely used in the passive management of fluid flow in pipeline systems or in measuring flowrates as a pressure drop device [23-25]. On the other hand, perforated plates are only pressure drop devices to simulate inside of the DSF' cavity for different conditions mentioned above in this study. For that purpose, two distinct perforated plates in order to create a pressure drop in the cavity were examined. The first results obtained from the experiments using a setup described below were given by Inan et al. [26]. However, the first results were about the airflow and heat transfer in a rectangular enclosure included natural flow. The experimental setup was reorganized for forced flow by using the perforated elements. The effect of these elements on the pressure drop and the air flow were experimentally analyzed. Moreover, temperature changes in the cavity for different working conditions were examined according to the experimental measurements.

\section{Experimental set-up}

\subsection{Test chamber}

Experimental setup is placed at the Building Physics Laboratory, which is on the ground floor of Block B of Faculty of Architecture, İzmir Institute of Technology. General view of the experimental setup in the laboratory can be seen in Fig. 1.

General plan of experimental setup can be also seen in Fig. 2. Accordingly, system consists of 8 major parts which are coded from I to VIII in Figs. 1 and 2.

Indoor environment simulation setup shown as I on Figs. 1 and 2, which is $1.5 \mathrm{~m}$ in width, $3 \mathrm{~m}$ in length, $3 \mathrm{~m}$ in height, is manufactured by using polyurethane thermal insulation panels which are $10 \mathrm{~cm}$ in thickness. One of its walls with short side is double-glazed in a size of 4-12-4 mm. Serpentines, which is $2.5 \mathrm{~m}$ in length, made up of thin aluminum plates around copper pipes where water coming from the cooling-heating bath shown in IV in Figs. 1 and 2 can circulate by using a pump, are placed on long walls of the setup in such a way they face each other. Temperature of the water can be maintained at a desired temperature by a thermostat located in the room. A thermally insulated door which can be opened both from inside and outside is placed at the other short wall of the indoor environment setup. Via this door, indoor environment can be accessed to place measuring probes and other possible interventions.

Outdoor environment simulation setup shown as II in Figs. 1 and 2, which is $1.5 \mathrm{~m}$ in width, $0.9 \mathrm{~m}$ in length, $3 \mathrm{~m}$ in height, is manufactured by using polyurethane thermal insulation panels which are $10 \mathrm{~cm}$ in thickness same as indoor environment. Its surface on solar simulator side is single-glazed $4 \mathrm{~mm}$ in thickness.
Other surface is in contact with the cavity of double facade which separates indoor and outdoor environments of the experiment room from each other. Cooling of the environment is performed with "air to refrigerant compact heat exchanger" to be hung on the two opposite wall surfaces. The outside unit of the cooling system (as V in Fig. 2) is located outside the building and it maintains the environment at the required temperature by directly circulating the refrigerant through the heat exchangers. In here, the extracted amount of heat is not measured; required temperature is provided to be kept constant with automation.

Experimental room intermediate partition (cavity) designed to simulate the double facade shown as III in Figs. 1 and 2. Single-glass component $4 \mathrm{~mm}$ in thickness on the outer surface of the double facade is positioned between the outdoor and indoor environments of the experiment room. Other surface of the intermediate region is empty and overlaps with the double glass facade of the indoor environment. Intermediate region is also insulated against heat transfer in the same way as indoor and outdoor environments. Collapsible clearances which are $20 \mathrm{~cm}$ in height and compose of the same type of glass are available at the lower and upper parts of the single-glass component of the cavity. Thus, it is provided to work on air flow modes within the double facade.

\subsection{Solar simulator unit}

Solar simulator unit shown as VI in Figs. 1 and 2 is air-cooled for preventing overheating. Whole support structure is made of aluminum. Weight is evenly distributed in the system and the tilting angle is set to approximately $45^{\circ}$. A completely modular system is chosen in relation to design. System can be moved up/down for $40 \mathrm{~cm}$ in the vertical direction with a motor controlled from the control panel. System consists of 12 lamps, 3 fans, moving partition, control board. Lamps are located so as to constitute a $3 \times 4$ matrix. Total electrical power is on the order of $13 \mathrm{~kW}$ approximately. Lamps consume $12 \mathrm{~kW}$ of this while the remaining is consumed by the fans and the control board. A fan system installed inside of the building exterior wall (mentioned FAN 2 in Fig. 2) is used for the removal of released energy from the solar simulator and the radial fan, $284 \mathrm{~W}$, rejects air at relatively high temperature through a duct system with a diameter of $315 \mathrm{~mm}$. Also, two fans available in the solar simulator unit contribute to this system.

\subsection{Mechanical ventilation system}

Fan with insulated duct system shown as VII in Figs. 1 and 2 is integrated into the system in order to ventilate the double facade. For this purpose, $500 \mathrm{~W}$, radial fan type is used. The capacity meets effect of pressure drops and the required flow rate values within the double facade. Fan sucks air from the outdoor environment simulating portion of the experimental setup. Air returns again the same portion via a $315 \mathrm{~mm}$ spiral channel system. Components are used at entry and exit points of the section which simulate the outdoor environment; also at entry and exit points of the fan system for transition from a rectangular cross section $\left(400^{*} 250 \mathrm{~mm}\right.$, $600 * 300 \mathrm{~mm}$, respectively for the aforementioned entry and exit points) to a circular cross section (Fig. 3). Sucking is performed from the bottom-left section and entry to the double facade is carried out with two distribution hoods. Three flexible channels with a diameter of $150 \mathrm{~mm}$ are used between these hoods; one of hood is mounted on the double facade. Moreover, the flow is made as homogeneous as possible by adding a perforated plate at the outlet of the hood (at the entry to the double skin facade). 


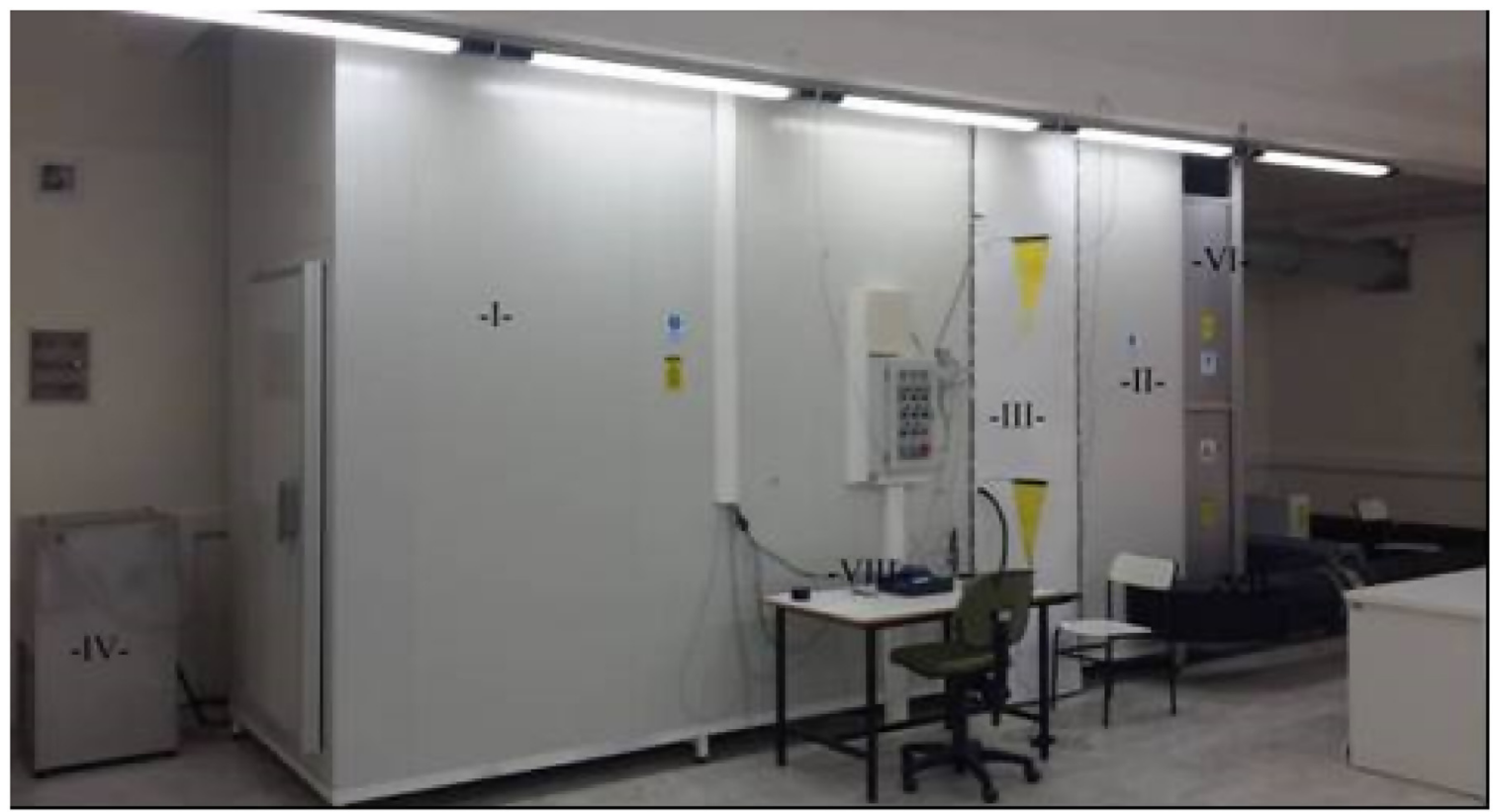

Fig. 1. Experimental setup layout in the laboratory.

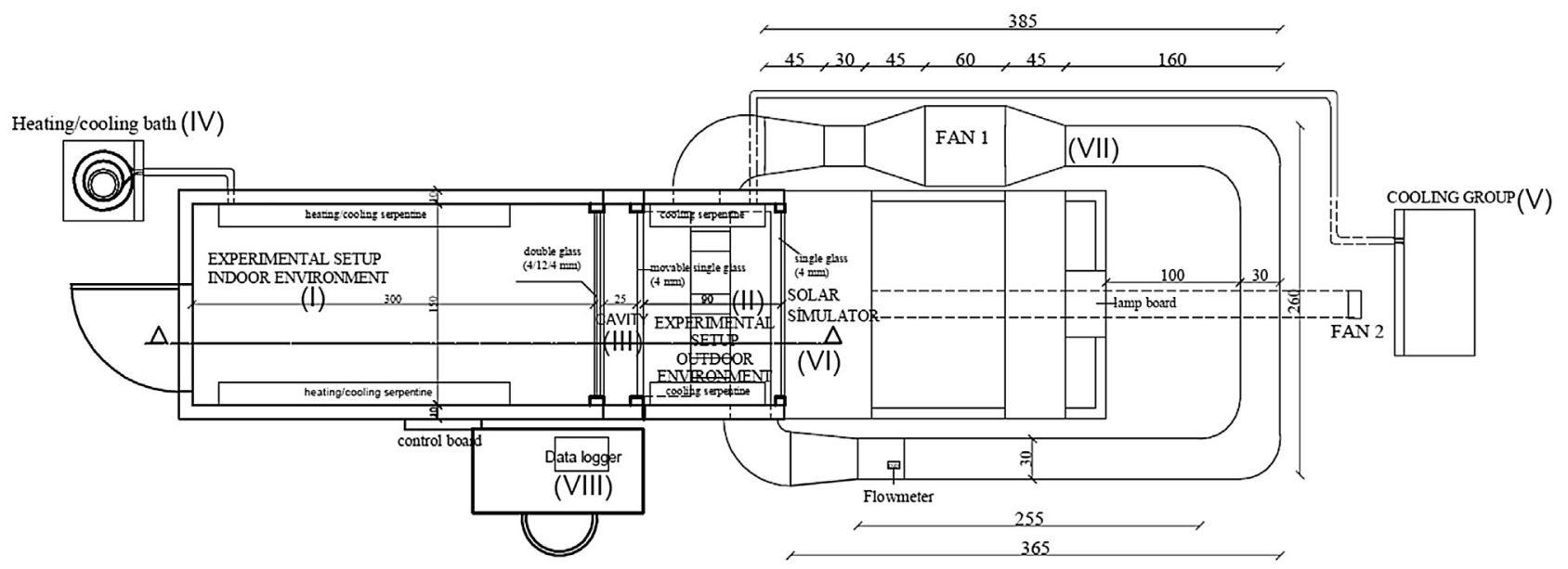

Fig. 2. Experimental setup plan.

Table 2

Characteristics of the perforated plates.

\begin{tabular}{|c|c|c|}
\hline Geometric definition & Perforated plates with big holes & Perforated plates with small holes \\
\hline hole diameter & $5 \mathrm{~mm}$ & $3 \mathrm{~mm}$ \\
\hline maximum distance between two adjacent holes & $14 \mathrm{~mm}$ & $9 \mathrm{~mm}$ \\
\hline minimum distance between two adjacent holes & $8 \mathrm{~mm}$ & $5 \mathrm{~mm}$ \\
\hline thickness of plate/hole diameter & 0.40 & 0.67 \\
\hline number of holes & 5140 & 16235 \\
\hline area of total holes & $1008.98 \mathrm{~cm}^{2}$ & $1146.19 \mathrm{~cm}^{2}$ \\
\hline area of plate & $3820 \mathrm{~cm}^{2}$ & $3880 \mathrm{~cm}^{2}$ \\
\hline porosity & 0.264 & 0.295 \\
\hline Plate net area/area of total holes & 2.79 & 2.38 \\
\hline equivalent porosity ratio & 0.51 & 0.54 \\
\hline
\end{tabular}




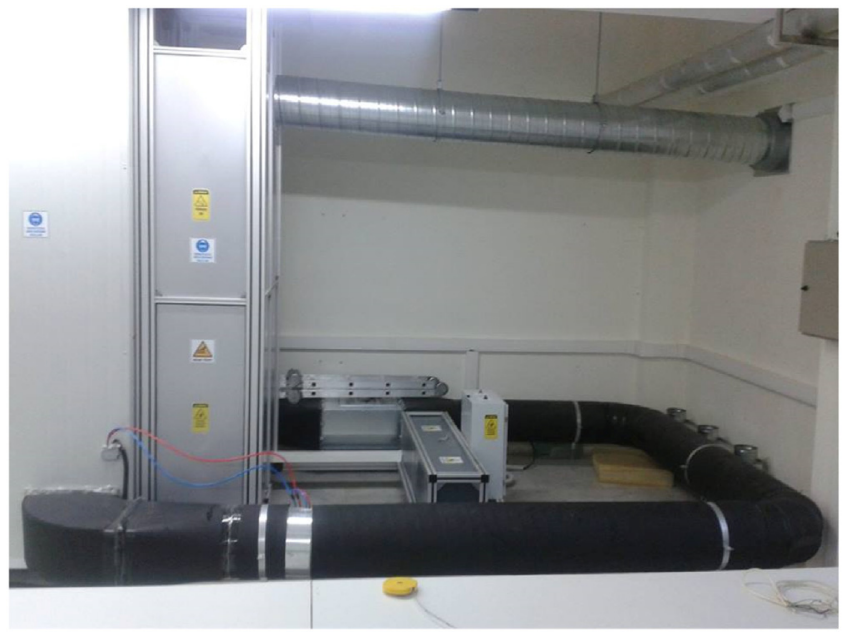

Fig. 3. General view of the duct system.

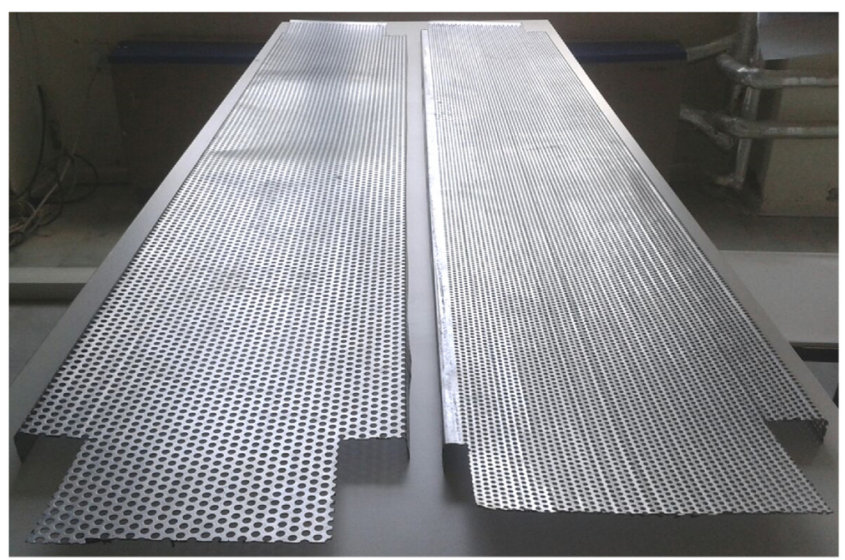

Fig. 4. Two different perforated plates.

\subsection{Perforated plates}

Two different kind of perforated plates shown in Fig. 4 are placed individually in the cavity. Plates' thickness is $2 \mathrm{~mm}$ each, holes are arranged staggered form through the perforated plates; diameter of them are $5 \mathrm{~mm}$ and $3 \mathrm{~mm}$ called big and small holes in Fig. 5 , respectively. The plates configuration is also characterized by different pitches between hole centers and the dimensions are given in $\mathrm{mm}$ in Fig. 5. The other characteristic dimensions are also given in Table 2.

\subsection{Measurement devices}

\subsubsection{Differential pressure measurements}

Approximately eight times of the diameter seen at the front side in Fig. 3 is left in order to determine clearly fully developed air flow in the straight duct. Velocity pressure is obtained with the apparatus which makes measurements according to working principle of Pitot tube (Fig. 6a). For this aim, HK Instruments DPT (Differential Pressure Transmitter) 2500-R8 model is used (it is mounted at outdoor unit wall as shown in Fig. 6a). This differential pressure measurement system operates in the range of $0-100 \mathrm{~Pa}$. This velocity pressure is measured with the differential pressure meter. This is recorded as voltage in the data recording system; then, these values are converted to the differential pressures which are finally converted to the velocity by using Bernoulli Equation.

Differential pressure measurement in the cavity is performed via two points placed within double facade at $120 \mathrm{~cm}$ intervals (marked with flags in Fig. 6b - aims to avoid accidental contacts). For this purpose, another HK Instruments DPT (Differential Pressure Transmitter) 2500-R8 model is used (Fig. 6b). This differential pressure measurement system is arranged to operate in the range of 0-25 Pa in this time. This differential pressure meter is put into use in the experimental study with respect to usage of components like perforated plates which are placed in the double facade and induce a pressure drop. Measurements are recorded as volt in the data logger; converted to differential pressure values in Pascal.
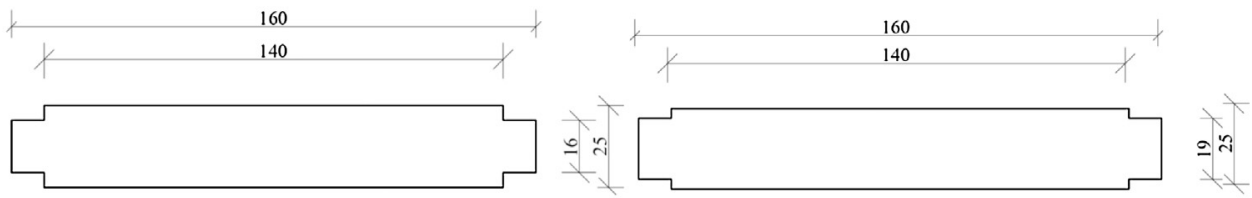

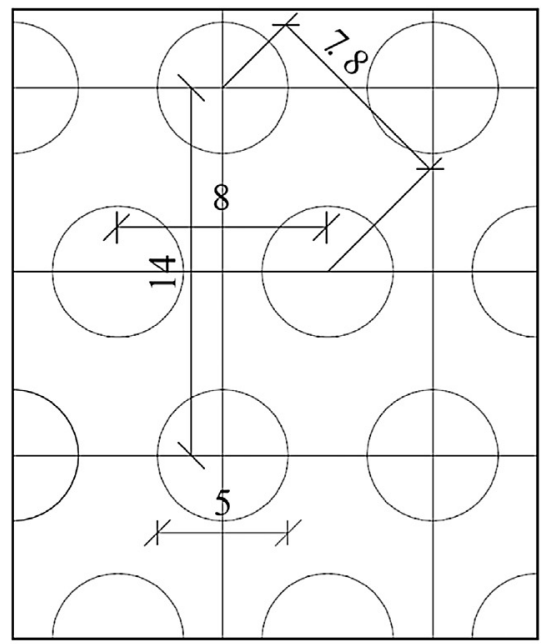

a) big holes $(5 \mathrm{~mm})$

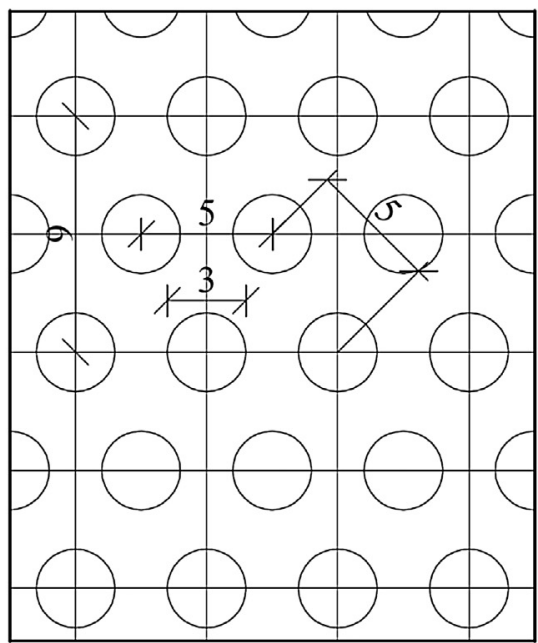

b) small holes ( $3 \mathrm{~mm})$

Fig. 5. Plans and dimensions of perforated plates (in $\mathrm{mm}$ ). 
(a)

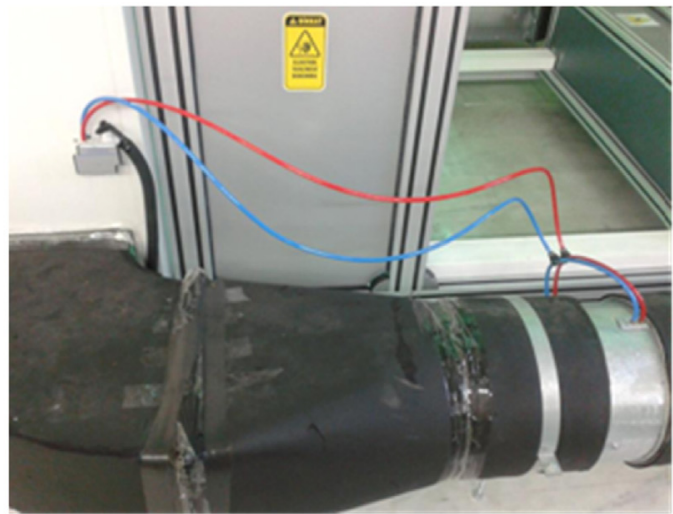

(b)

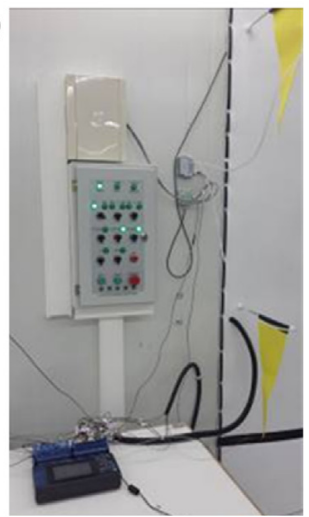

Fig. 6. Differential pressure measurement systems.

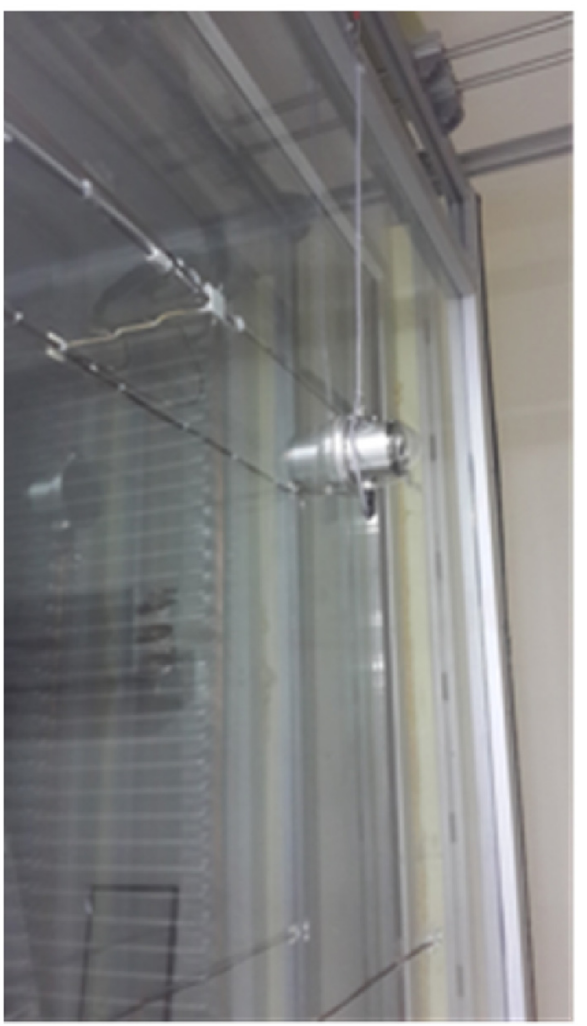

Fig. 7. MS-410 Pyranometer position on the experimental room.

\subsubsection{Pyranometer}

Heat flux obtained from the solar simulator on the outer surface of double facade (outdoor environment part of the experiment room) as shown in Fig. 7 is measured with the MS-410 pyranometer. The position of the pyranometer is fixed on the outer side of the exterior facade that gives the average solar radiation value previously determined experimentally.

\subsubsection{Temperature measurements}

T-type thermocouples are used for temperature measurements at different surfaces and environments of the experimental setup. In the experimental setup, PT 100 probes are used for temperature measurements of the indoor environment as well as inlet/outlet temperatures of heating-cooling water bath. T-type thermocouples are used in the other parts. Eight thermocouples namely CA1-8 are placed inside the cavity in order to determine variation of the air temperature (CA3,4,7,8 can be seen in Fig. 8; CA1,2,5,6 are positioned at the projection of the other four thermocouples). Air temperature inside the environment simulating the outdoor environment is measured with two thermocouples which are numbered as D1, D2 in Fig. 8 at two different points. Air temperature in the section simulating the indoor environment is measured at three different points (AI1, AI2, AI3 in Fig. 8).

Six T-type thermocouples are placed symmetrically at each two different surfaces in order to measure inner surface temperatures of the double facade. These thermocouples are coded primary facade outer glass, PFOG1 to 6 for the portion of the cavity facing the inner room; from secondary facade inner glass, SFIG1 to 6 for the portion of the cavity facing the outer room. Temperature measurements taken at different points of the experimental setup with T-type thermocouples and PT-100 probes are recorded with the HIOKI type data logger shown in Figs. 1 and 2 (shown in VIII).

\subsection{Calibration process and uncertainty analysis}

\subsubsection{Calibration process}

Calibrations of each one of all PT-100 probes and thermocouples used in the experimental setup were performed in the calibration laboratory of Izmir Chamber of Mechanical Engineers. Based on the results of the calibration measurements, when the temperatures obtained from the experiments were taken into account.

Differential pressure measurement systems were selfcalibrated in case pressure values were same at the two openings where the pressure difference was measured and no pressure generating effect was available, measurement system was set to zero.

Pyranometer system was also used as calibrated. Because pyranometer sensor measured heat flux at $7.2 \mathrm{~cm}$ behind the secondary facade. Firstly, the position of the pyranometer was determined. For that, two different measurements were conducted in the points over the glass surface by changing the distance between the secondary facade glass to the solar simulator. The change of heat flow over the glass surface was specified by measuring from two different distances. The position over the secondary glass surface of the pyranometer was considered by calculating the average heat flux for both situations. After these measurements, it was found that pyranometer should be located under the $55 \mathrm{~cm}$ of the upper glass surface; right at the middle axis. This point reflects the average heat flux values for the both measurement which were $474.8 \mathrm{~W} / \mathrm{m}^{2}, 574.5 \mathrm{~W} / \mathrm{m}^{2}$; the standard deviation values were $66.8 \mathrm{~W} / \mathrm{m}^{2}, 80.1 \mathrm{~W} / \mathrm{m}^{2}$, respectively.

\subsubsection{Uncertainty analysis}

The experimental uncertainty calculations were carried out in the scope of the method followed by the Holman [27], Tokuç et al. 


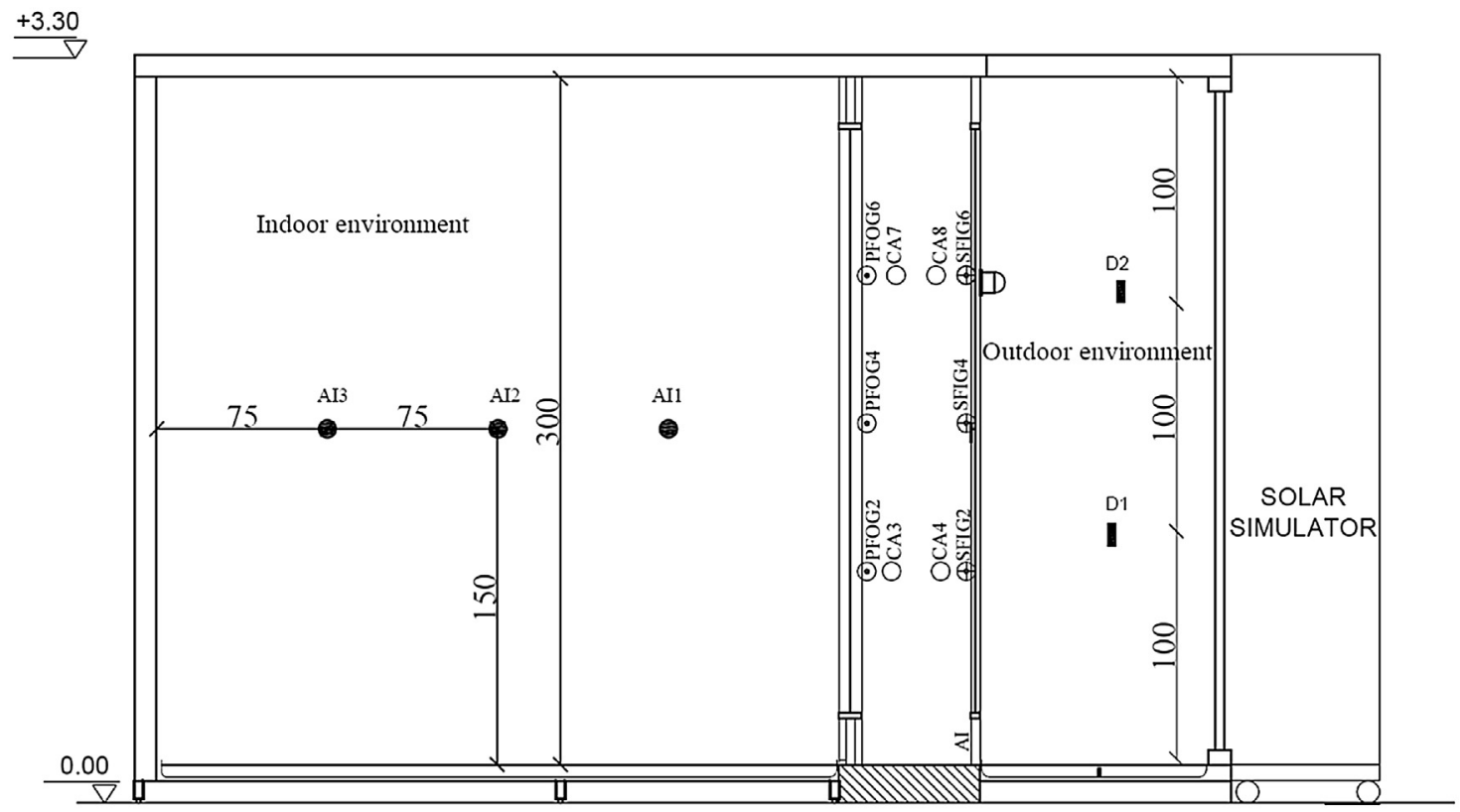

Fig. 8. Temperature measurement points at indoor and outdoor simulation rooms of experimental set up section mentioned in Fig. 2 (in cm).

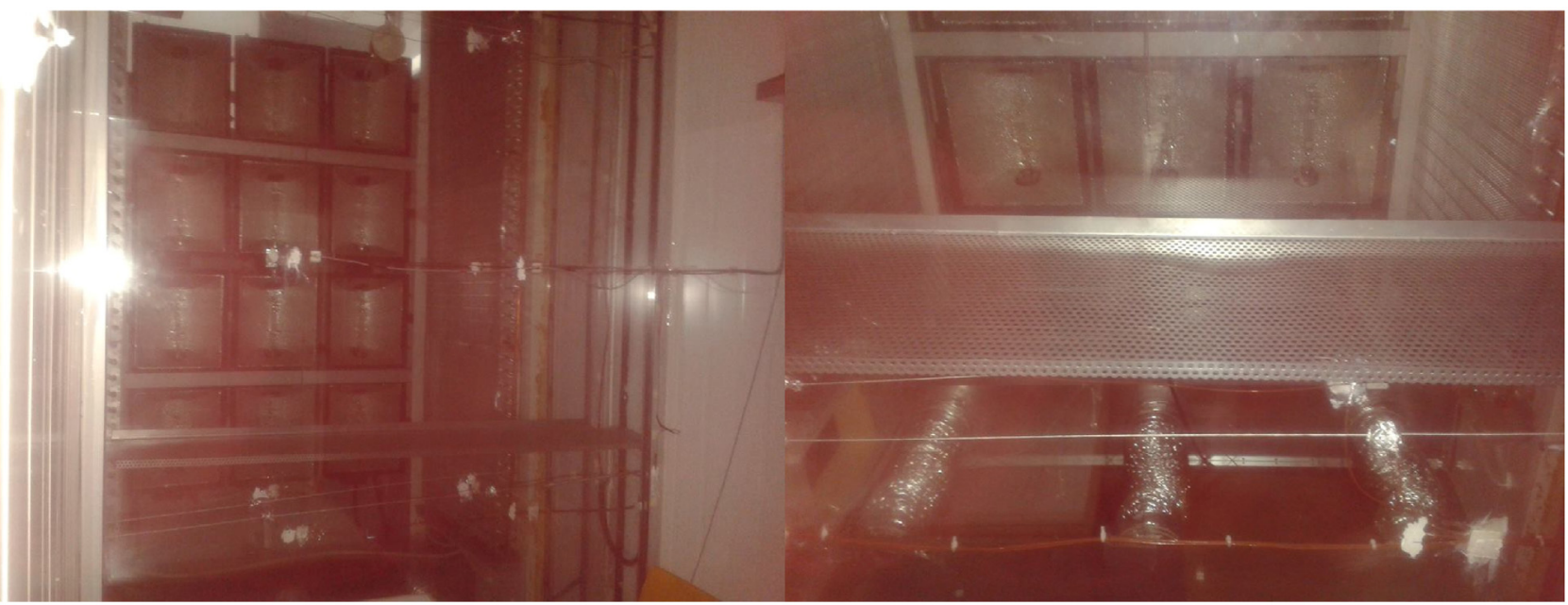

Fig. 9. Layout of perforated plates in the cavity of DSF.

[28]. According to that, the uncertainty of each device affected the total uncertainty of the value $(R)$ obtained with the use of these devices. If $\mathrm{R}$ value was expressed depending on the independent variables of $\mathrm{x}_{1}, \mathrm{x}_{2}, \mathrm{x}_{3}, \ldots \mathrm{x}_{\mathrm{n}}$ given in Eq. (1):

$\mathrm{R}=\mathrm{R}\left(\mathrm{x}_{1}, \mathrm{x}_{2}, \mathrm{x}_{3}, \ldots \mathrm{x}_{\mathrm{n}}\right)$

If it was defined the $\omega_{R}$ as the uncertainty of the value calculated, it was obtained Eq. (2) formulas in consideration of the uncertainty of the all independent variables.

$\omega_{\mathrm{R}}=\left[\left(\frac{\partial \mathrm{R}}{\partial \mathrm{x}_{1}} \omega_{1}\right)^{2}+\left(\frac{\partial \mathrm{R}}{\partial \mathrm{x}_{2}} \omega_{2}\right)^{2}+\ldots+\left(\frac{\partial \mathrm{R}}{\partial \mathrm{x}_{\mathrm{n}}} \omega_{\mathrm{n}}\right)^{2}\right]^{1 / 2}$

The uncertainty analysis of the mass flow rate flown through the duct system connected with the DSF' cavity for the experimental works in the steady-state condition was conducted. According to that, the mass flow rate was defined in Eq. (3):

$\dot{m}=\rho_{a} A_{c} V_{a}$
The uncertainty in relation to Eq. (3) was due to the density of the air $\left(\rho_{a}\right)$, velocity of the air $\left(V_{a}\right)$, the cross section area that the air passes $\left(A_{c}\right)$. According to that, parameters that affect the mass flow rate were defined for air in Eq. (4);

$\dot{m}=f\left(\rho_{a}, V_{a}, A_{c}\right)$

The uncertainty value of each independent property was given in Table 3. According to that the uncertainty of the mass flow rate to be calculated depending on the parameters defined in Eq. (4) for air were specified with the solution of Eq. (2). According to that total uncertainty in the mass flow rate of the air was calculated in consideration of the values in Table 3 as; $5.4 \%$. Furthermore, the uncertainty in relation to the differential pressure meter was defined as $\pm \% 1.5+1 \mathrm{~Pa}$. The uncertainty of the pyranometer was also given as $7.00 \mu \mathrm{V} / \mathrm{Wm}^{-2}$.

The total uncertainty value for the thermocouples was evaluated together with the uncertainty of the devices used in consideration of the calibration proceeding. According to that, the uncertainty value for the thermocouples: 
Table 3

The uncertainty value of each independent property used in the experimental studies.

\begin{tabular}{llll}
\hline Variables & Value & Uncertainty & Comment \\
\hline Air density, $\rho_{a}$ & $\begin{array}{l}1.184 \mathrm{~kg} / \mathrm{m}^{3} \\
@ 25^{\circ} \mathrm{C}\end{array}$ & $\pm \% 0.02$ & $\begin{array}{l}\text { Uncertainty in the } \\
\text { density of air }\end{array}$ \\
$\begin{array}{c}0.1-10 \mathrm{~m} / \mathrm{s} \\
\text { Air velocity, } V_{a}\end{array}$ & $\pm \% 5$ & $\begin{array}{l}\text { Uncertainty from the } \\
\text { flow measurement }\end{array}$ \\
$\begin{array}{c}\text { Sectional area } \\
\text { which the air }\end{array}$ & $0.0779 \mathrm{~m}^{2}$ & $\pm \% 2$ & $\begin{array}{l}\text { Uncertainty from the } \\
\text { measurement of the } \\
\text { passes, } A_{c}\end{array}$ \\
& & $\begin{array}{l}\text { cross-sectional area of } \\
\text { the air flows }\end{array}$ \\
\hline
\end{tabular}

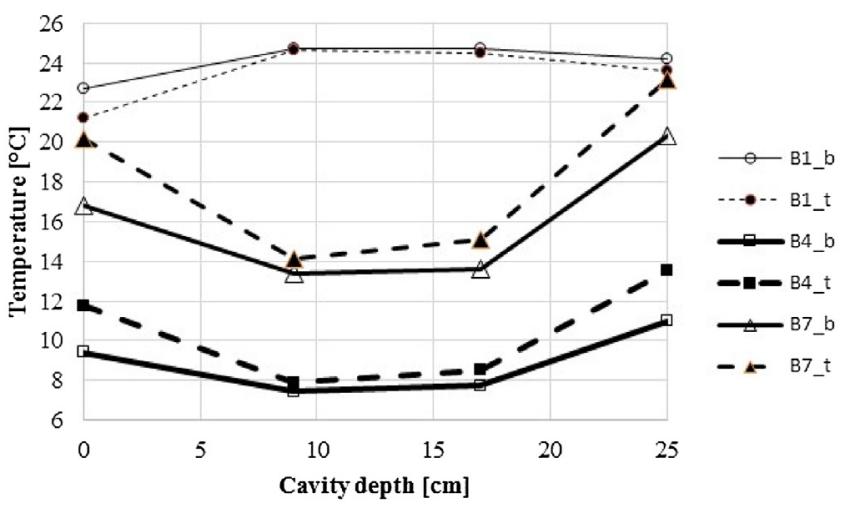

Fig. 10. Temperature distributions in the cavity at the bottom (b) and top (t) levels for three experiments (1, 4 and 7$)$ on big (B) hole perforated plate.

$\sqrt{\left(\frac{\text { refPt } 100}{2}\right)^{2}+\left(\frac{T_{\mathrm{cc}} / 2}{\sqrt{3}}\right)^{2}+\left(\frac{\text { ref mm }}{2}\right)^{2}+S t^{2}+B_{\text {sta }}^{2}}= \pm 0.034^{\circ} \mathrm{C}$

The maximum resolution for refPt100 value for Pt-100 probe used as a reference in the calibration in Eq. (5) was taken as $0.02{ }^{\circ} \mathrm{C}$ $\left(0.01{ }^{\circ} \mathrm{C}\right.$ for $0{ }^{\circ} \mathrm{C} ; 0.02{ }^{\circ} \mathrm{C}$ for $\left.100^{\circ} \mathrm{C}\right)$. Test device, the resolution of Hioki LR 8401-20, $T_{c \zeta}$ was the maximum $0.1^{\circ} \mathrm{C}$ for the thermocouples. The resolution value of the reference multimeter used in the calibration, refmm, was $0.0024^{\circ} \mathrm{C}$. Standard deviation, St, was maximum $0.01{ }^{\circ} \mathrm{C}$; bath stability, $B_{\text {st a }}$ was taken as $0.01{ }^{\circ} \mathrm{C}$. According to Eq. (5), uncertainty value for Pt 100 probes used in the experiment were also calculated as $\pm 0.018^{\circ} \mathrm{C}$.

\section{Experimental results and discussions}

Perforated plates shown in Fig. 9 were placed in the cavity of the DSF in the experimental setup. In here, dimensions of circular holes on the plate, $5 \mathrm{~mm}$ were greater than the other plate used as shown by the experimental results (Figs. 10 and 11), pressure drop generated by it was lower. After finishing nine experimental studies with big hole plate, small hole $(3 \mathrm{~mm})$ plate was used another nine experiments under steady state conditions. General view of the perforated plates and their dimensions were seen in Figs. 4 and 5. Detailed geometric configurations of the plates were also given in Table 2 .

Totally 18 experimental measurements were conducted by using two perforated plates having different size in this study. The experimental setup was run for each test and steady-state conditions were waited before measurements were taken. Temperature values at each point in the experimental setup mentioned in Fig. 8 were recorded at $2 \mathrm{~s}$ intervals. All system was thermal equilibrium in the beginning, after that different temperatures were created inside of the indoor and outdoor environments by using a constant temperature water bath and a refrigeration-based cooling

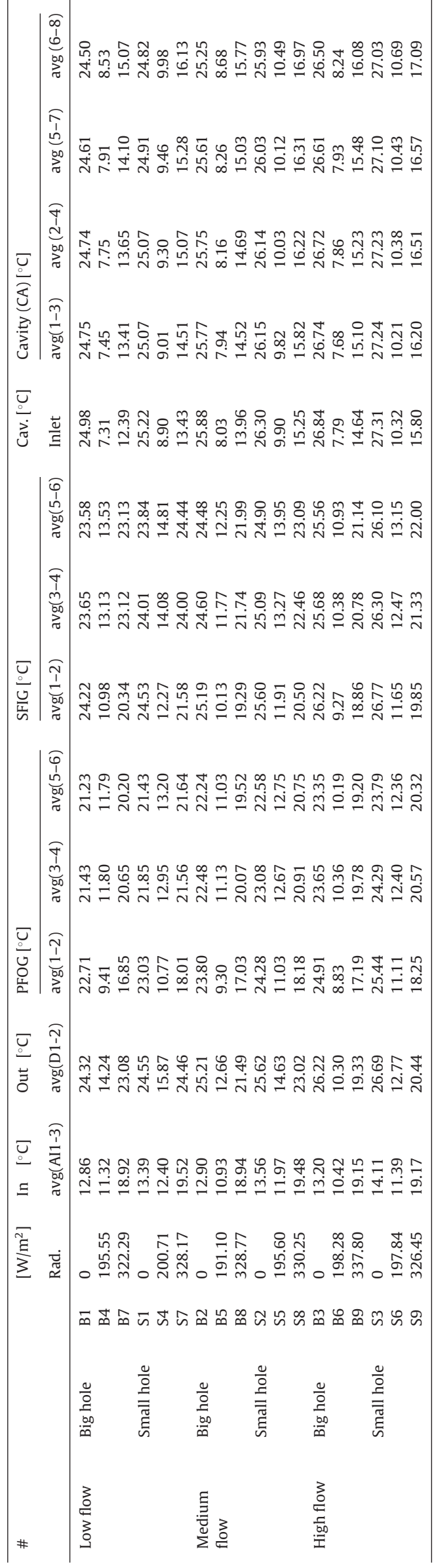




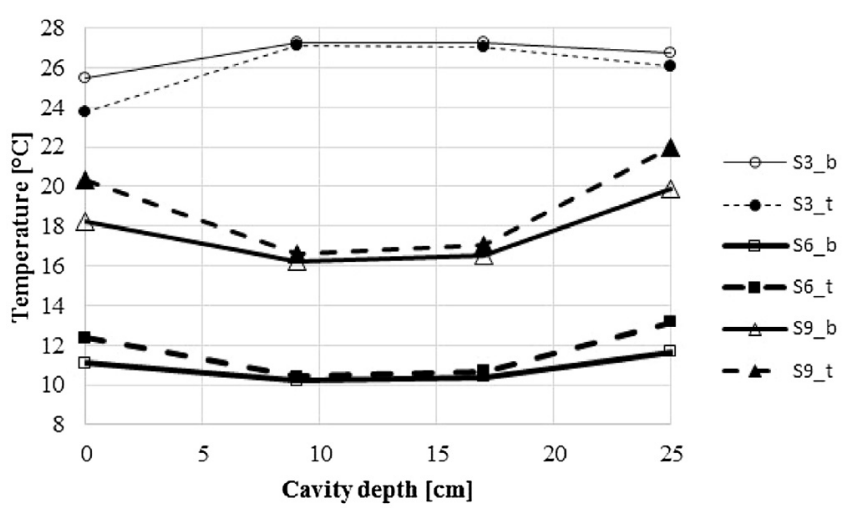

Fig. 11. Temperature distributions in the cavity at the bottom (b) and top (t) levels for three experiments (3, 6 and 9) on big (S) hole perforated plate.

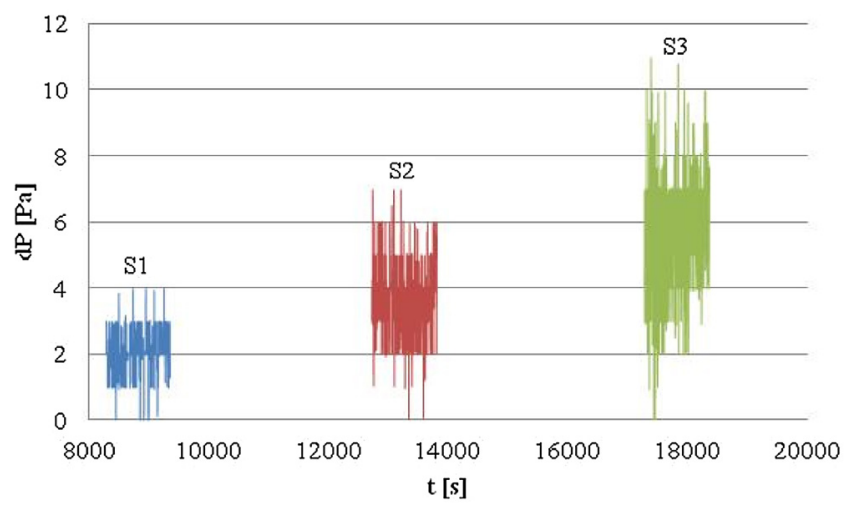

Fig. 12. Pressure drop on small hole perforated plate for three distinct flow rates for the experiments numbered S1, S2 and S3.

system, respectively, as shown in Figs. 1 and 2. Solar simulator system was also run in the some of the experiments. These different temperatures for two environments become stable after a while. The temperature values which were in the indoor environment reflected the average value of 3 thermocouples (AI1-3 in Fig. 8). Thermocouples D1, 2 (Fig. 8) gave the average temperature values of the outdoor environment.

The average temperature distribution on the two different height (mentioned as b for bottom; $t$ for top) section of the cavity after steady state condition were given in Figs. 10 and 11 for the six experiments on the big (mentioned as B1, 4, 7 in Fig. 10) and small (mentioned as S3, 6, 9 in Fig. 11) hole perforated plates individually. Average temperature values of the cavity air at two levels for each measurement were also given in the middle with the temperatures on the two sides referred to the average surface temperatures (Figs. 10 and 11). All measurements were obtained by using two thermocouples at different depth at the same level. Heat transfer occurred due to these temperature differences from two surfaces to the air because of heated surfaces by solar radiation at the experiments numbered B4, 7 and S6, 9. High solar radiation created bigger temperature changes relatively at the B7, S9. On the other hand, heat transferred from relatively hot air (cavity air inlet temperature is a small quantity bigger than the outside temperature: $24.98^{\circ} \mathrm{C}>24.32^{\circ} \mathrm{C}$ for $\mathrm{B} 1 ; 27.31^{\circ} \mathrm{C}>26.69^{\circ} \mathrm{C}$ for $\mathrm{S} 3$ given in Table 4) to the surfaces at no solar radiation situations at the experiments B1, S3.

All the temperature measurements with the solar radiation values at the steady state condition were given in Table 4. Air flow rate at three different levels mentioned low, medium and high; the relative size of perforated plate's hole could be seen in the first two columns of the table. Third column was about the number of exper- iments. Solar radiation values at fourth column were created by solar simulator (numbered VI in Figs. 1 and 2) and measured by the pyranometer shown in Fig. 7 separately. The other columns were about the average temperature values measured by thermocouples and probes mentioned in Fig. 8.

For the small hole perforated plate, time dependent behavior of the pressure drops obtained with respect to different flow rates applied in the experimental studies numbered S1-S3 were shown in Fig. 12 for the case following the experiment come at steady state. System firstly reached the steady-state condition thermally after $8000 \mathrm{~s}$ for the first experiment called S1. The empty sections shown in Figs. 12 and 13 were about unsteady condition between recorded measurement data.

Pressure drop in big hole perforated plate was given in Fig. 13. Pressure drop with respect to Fig. 12 somewhat decreased in Fig. 13 due to larger holes. Mean values showed this decrease more clearly. Pressure drop also increased instinctively by an increase in the flow rate values for each cases that could be seen in Figs. 12 and 13.

Experimental results, variation of pressure drop induced by using distinct perforated plates with the mass flow rates were given in Table 5. In here, mass flow rate was calculated by using average value of the steady-state pressure drop values measured and recorded in the circular duct for each case; then the mean value of velocity was calculated by Bernoulli Equation. Density of air like the other thermosphysical properties, was used separately for the value corresponding to the relevant temperature. Duct system with the pressure drop measurement used for the calculation of the mass flow rate in the duct were shown in Figs. 3, 6 a, respectively. Calculated mass flow rate values with the average velocities induced by measured pressure drop values were given in the columns together at the duct section in Table 5. Cavity's columns were about the calculations of the cavity air in DSF. Average velocity values at the cavity were determined using mass flow rates in the duct and obtained lower values because of increasing cross section area of the cavity. Reynolds numbers, $R e$, were calculated by using these velocity values with hydraulic diameter and kinematic viscosity of air:

$R e=\frac{V D_{h}}{v}$

where $V, D_{h}, v$ were defined as velocity, hydraulic diameter, kinematic viscosity of air. Euler numbers, $E u$, dimensionless pressure drop coefficients, were used in the definition of the flow in the perforated plate applications and defined as;

$E u=\frac{\Delta P}{1 / 2 \rho V^{2}}$

where $\Delta P$ was defined as pressure drop between downstream and upstream. In here, $\Delta P$ was measured by the differential pressure measurement system shown in Fig. 6b. So, Eu numbers were calculated using measured pressure drop $(\Delta P)$, average velocity $(V)$ values with air density $(\rho)$ in Eq. (7).

Graphical representation for the values given in Table 5 was cited in Fig. 14. Pressure drops induced by using distinct perforated plates versus different mass flow rates could be seen for the experimental results mentioned different markers in Fig. 14. Pressure drops generated by small hole plate were significantly higher than the big one and it could be clearly seen that the difference became to be bigger with increase in mass flow rate. The pressure drop values depended to a power function of the mass flow rate values. The lines were drawn using average (mentioned as A in Fig. 14) values and defined as;

$$
\begin{aligned}
& \Delta P_{S}=0.694 e^{2.831 \dot{m}} \\
& \Delta P_{B}=0.144 e^{4.353 \dot{m}}
\end{aligned}
$$




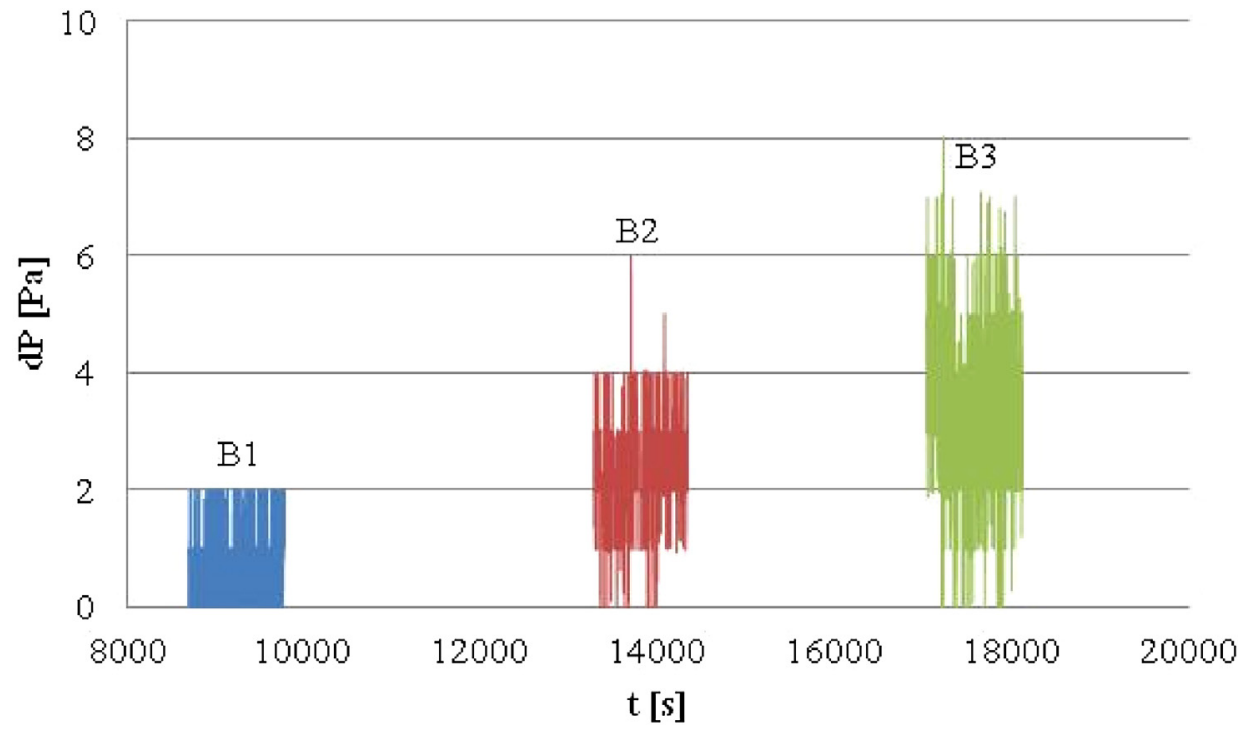

Fig. 13. Pressure drop on big hole perforated plate for three distinct flow rates for the experiments numbered B1, B2 and B3.

Table 5

Air flow measurements in the duct and the variation of pressure drop induced by using distinct perforated plates in the cavity.

\begin{tabular}{|c|c|c|c|c|c|c|c|c|c|}
\hline \multirow[t]{2}{*}{ \# } & & & \multicolumn{3}{|l|}{ Duct } & \multicolumn{4}{|l|}{ Cavity } \\
\hline & & & $\Delta \mathrm{P}[\mathrm{Pa}]$ & $\mathrm{V}[\mathrm{m} / \mathrm{s}]$ & $\dot{\mathrm{m}}[\mathrm{kg} / \mathrm{s}]$ & $\mathrm{V}[\mathrm{m} / \mathrm{s}]$ & $\operatorname{Re}[-]$ & $\Delta \mathrm{P}[\mathrm{Pa}]$ & $\mathrm{Eu}[-]$ \\
\hline \multirow[t]{6}{*}{ Low flow } & \multirow[t]{3}{*}{ Big hole } & B1 & 8.590 & 3.81 & 0.352 & 0.78 & 20,510 & 0.784 & 2.188 \\
\hline & & B4 & 7.382 & 3.43 & 0.336 & 0.70 & 20,529 & 0.831 & 2.705 \\
\hline & & B7 & 6.879 & 3.35 & 0.322 & 0.68 & 19,388 & 0.122 & 0.425 \\
\hline & \multirow[t]{3}{*}{ Small hole } & $\mathrm{S} 1$ & 10.371 & 4.19 & 0.386 & 0.84 & 22,509 & 2.061 & 4.932 \\
\hline & & S4 & 9.414 & 3.88 & 0.378 & 0.78 & 23,008 & 2.219 & 5.855 \\
\hline & & S7 & 6.877 & 3.35 & 0.321 & 0.67 & 19,280 & 1.488 & 5.362 \\
\hline \multirow{6}{*}{$\begin{array}{l}\text { Medium } \\
\text { flow }\end{array}$} & \multirow[t]{3}{*}{ Big hole } & B2 & 22.098 & 6.12 & 0.563 & 1.25 & 32,747 & 2.251 & 2.448 \\
\hline & & B5 & 20.239 & 5.68 & 0.556 & 1.16 & 33,884 & 1.880 & 2.229 \\
\hline & & B8 & 21.156 & 5.88 & 0.562 & 1.20 & 33,679 & 1.584 & 1.802 \\
\hline & \multirow[t]{3}{*}{ Small hole } & $\mathrm{S} 2$ & 24.364 & 6.43 & 0.591 & 1.29 & 34,390 & 3.705 & 3.766 \\
\hline & & S5 & 21.755 & 5.91 & 0.574 & 1.19 & 34,830 & 3.778 & 4.309 \\
\hline & & S8 & 21.232 & 5.90 & 0.562 & 1.18 & 33,611 & 3.215 & 3.754 \\
\hline \multirow[t]{6}{*}{ High flow } & \multirow[t]{3}{*}{ Big hole } & B3 & 37.756 & 8.01 & 0.735 & 1.63 & 42,653 & 3.415 & 2.172 \\
\hline & & B6 & 37.656 & 7.75 & 0.758 & 1.58 & 46,222 & 3.465 & 2.213 \\
\hline & & B9 & 37.965 & 7.88 & 0.753 & 1.61 & 41,778 & 3.415 & 2.159 \\
\hline & \multirow[t]{3}{*}{ Small hole } & S3 & 39.392 & 8.19 & 0.750 & 1.65 & 43,541 & 5.599 & 3.522 \\
\hline & & S6 & 37.802 & 7.79 & 0.756 & 1.57 & 45,850 & 6.301 & 4.136 \\
\hline & & S9 & 35.659 & 7.65 & 0.728 & 1.53 & 43,461 & 5.129 & 3.564 \\
\hline
\end{tabular}

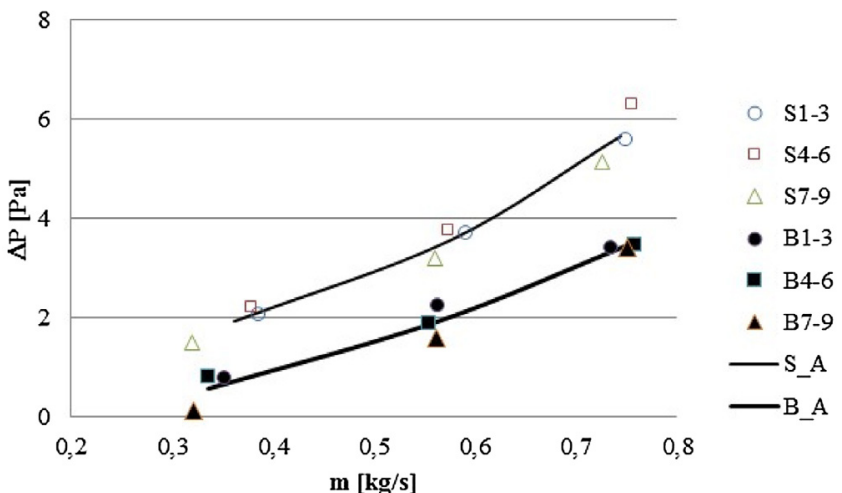

Fig. 14. Variation of pressure drop induced by using distinct perforated plates and flow rate.

where the equations numbered 8, 9 were derived for the small (S), big (B) hole perforated plates, respectively. $\mathrm{R}^{2}$ values were calculated as 0.9998; 0.9797, respectively.

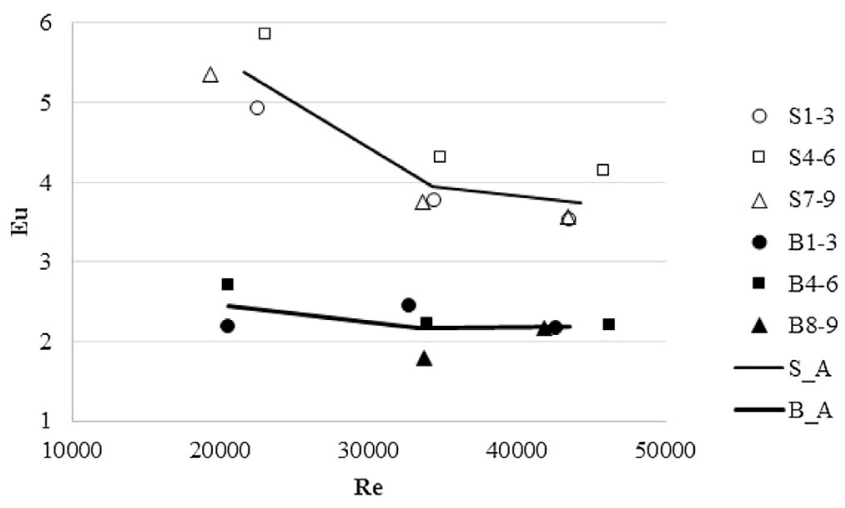

Fig. 15. Dimensionless pressure loss coefficients versus Reynolds numbers.

The changes of $E u$ as a function of Re were given in Fig. 15 for two distinct perforated plates. Pressure drop dimensionless coefficient, $\mathrm{Eu}$, was stabilized after first three experiments for each hole case. Average $E u$ numbers were determined considered this second part 
Table 6

Effect of the hole geometric parameters upon the dimensionless pressure loss coefficient, $E u$ (from the reference numbered [23]).

\begin{tabular}{|c|c|c|c|c|}
\hline & thickness of the plate/hole diameter [-] & number of holes [number] & equivalent porosity ratio [-] & Eu $[-]$ \\
\hline Current study & 0.40 & 5140 & 0.51 & 2.2 \\
\hline Current study & 0.67 & 16,235 & 0.54 & 3.8 \\
\hline Weber et al. [29] & 0.48 & 3052 & 0.48 & 21.018 .8 \\
\hline Weber et al. [29] & 0.32 & 4534 & 0.57 & 10.89 .9 \\
\hline Weber et al. [29] & 0.32 & 7093 & 0.71 & 2.43 .2 \\
\hline
\end{tabular}

of the lines in Fig. 15. This values were given in Table 6 with the other values in the literature [29].

In this study, the dimensionless parameters found that thickness of the plate divided by hole diameter were measured as 0.40 and 0.67 , respectively. But, equivalent porosity ratios were calculated as 0.51 and 0.54 close to each other (Table 2). These values were very effective of the dimensionless pressure loss coefficient, $E \mathbf{E u}$. $\mathrm{u}$ numbers of the big and small hole perforated plates were calculated as 2.2 and 3.8, respectively. These values could be acceptable considering Weber et al. [29]'s study.

\section{Conclusions}

Two distinct perforated plates are installed inside the DSF's cavity for investigating of the pressure drop effect experimentally under different working conditions. To the best of the authors' knowledge, this work is one of the first study considering pressure drop elements inside the cavity of DSF. Different kind of solar shading devices, plants and the perforated elements installed in the corridor type DSF are the different type of pressure loss elements in the cavity. Here, that pressure loss effect is created by using two different perforated elements. Findings and major conclusions can be described as:

- Pressure drops created by perforated plates in the cavity of DSF; temperature distributions created by water and refrigeration based systems with a solar simulator were examined based on the experimental measurements. All experimental results with the surface and air temperature distributions in the cavity; pressure drops under three different air flow rates and two distinct perforated plates having different geometric configurations were described in the study.

- There is no significant relation between the solar radiation effect along the dimensionless pressure drop coefficient. Solar radiation affected the surface temperature values of the cavity.

- Two correlations included the pressure drop and the mass flow rate values were constructed to evaluate the pressure loss in the DSF's cavity under mentioned working conditions of the study. Pressure drop created by different type of elements in the DSF's cavity must be considered for ventilating the cavity and choosing the fan capacity in the DSF applications.

- Big diameter perforated plate created lower pressure drop relatively compering with the small one.

- The dimensionless pressure drop coefficient, $\mathrm{Eu}$, versus Reynolds number were determined experimentally for different geometric characteristic of the perforated plates. Eu numbers is independent of the Re numbers after 30,000 approximately as mentioned studies numbered 23 and 24 .

- Results from the 18 experimental studies under steady-state conditions were collected to create an extended data set for the validation of numerical studies. A porous media approximation can be useful to predict the air flow characteristics in the cavity as mentioned in the references numbered 11 and 16 for future studies.

\section{Acknowledgment}

This work was supported by the Scientific and Technological Research Council of Turkey (TÜBITAK) Foundation under grant number 112M170.

\section{References}

[1] F. Pomponi, P.A.E. Piroozfar, R. Southall, P. Ashton, E.R.P. Farr, Energy performance of double-skin façades in temperate climates: a systematic review and meta-analysis, Renew. Sustain. Energy Rev. 54 (2016) 1525-1536.

[2] A. Ghaffarianhoseini, A. Ghaffarianhoseini, U. Berardi, J. Tookey, D.H.W. Li, S. Kariminia, Exploring the advantages and challenges of double-skin facades (DSFs), Renew. Sustain. Energy Rev. 60 (2016) 1052-1065.

[3] T. Zhang, Y. Tan, H. Yang, X. Zhang, The application of air layers in building envelopes: a review, Appl. Energy 165 (2016) 707-734.

[4] W.J. Stec, A.H.C. van Paassen, A. Maziarz, Modelling the double skin facade with plants, Energy Build. 37 (5) (2005) 419-427.

[5] W.J. Stec, A.H.C. van Paassen, Symbiosis of the double skin facade with the HVAC system, Energy Build. 37 (5) (2005) 461-469.

[6] S.K. Chou, K.J. Chua, J.C. Ho, A study on the effects of double skin façades on the energy management in buildings, Energy Convers. Manage. 50 (2009) 2275-2281.

[7] R. Fuliottoa, F. Cambulia, N. Mandasa, N. Bacchinb, G. Manarab, Q. Chen, Experimental and numerical analysis of heat transfer and airflow on an interactive building facade, Energy Build. 42 (1) (2010) 23-28.

[8] V. Gavan, M. Woloszyn, F. Kuznik, J.J. Roux, Experimental study of a mechanically ventilated double-skin facade with venetian sun-shading device: a full-scale investigation in controlled environment, Sol. Energy 84 (2010) 183-195

[9] F. Kuznik, T. Catalina, L. Gauzere, M. Woloszyn, J.J. Roux, Numerical modelling of combined heat transfers in a double skin facade-full-scale laboratory experiment validation, Appl. Therm. Eng. 31 (14-15) (2011) 3043-3054.

[10] M. Bhamjee, A. Nurick, D.M. Madyira, An experimentally validated mathematical and CFD model of a supply air window: forced and natural flow, Energy Build. 57 (2013) 289-301.

[11] N. Safer, M. Woloszyn, J.J. Roux, Tree-dimensional simulation with a CFD tool of the airflow phenomena in single floor double skin facade equipped with a venetian blind, Sol. Energy 79 (2) (2005) 193-203.

[12] A. Pappas, Z. Zhai, Numerical investigation on thermal performance and correlations of double skin facade with buoyancy-driven airflow, Energy Build. 40 (2008) 466-475.

[13] X. Xu, Z. Yang, Natural ventilation in the double skin facade with venetian blind, Energy Build. 40 (8) (2008) 1498-1504

[14] T.E. Jiru, F. Haghighat, Modeling ventilated double skin facade-A zonal approach, Energy Build. 40 (8) (2008) 1567-1576.

[15] W. Fang, Z. Xiaosong, T. Junjie, L. Xiuwei, The thermal performance of double skin facade with Tillandsia usneoides plant curtain, Energy Build. 43 (9) (2011) 2127-2133

[16] Z. Zeng, X. Li, C. Li, Y. Zhu, Modeling ventilation in naturally ventilated double-skin facade with a venetian blind, Build. Environ. 57 (2012) 1-6.

[17] D. Iyi, R. Hasan, R. Penlington, C. Underwood, Double skin facade: modelling technique and influence of venetian blinds on the airflow and heat transfer, Appl. Therm. Eng. 71 (1) (2014) 219-229.

[18] S.F. Larsen, C. Filippin, G. Lesino, Thermal simulation of a double skin facade with plants, Energy Procedia 57 (2014) 1763-1772.

[19] F.M. da Silva, M.G. Gomes, A.M. Rodrigues, Measuring and estimating airflow in naturally ventilated double skin facades, Build. Environ. 87 (2015) 292-301.

[20] N. Nasrollahi, M. Salehi, Performance enhancement of double skin facades in hot and dry climates using wind parameters, Renew. Energy 83 (2015) 1-12.

[21] W. Choi, J. Joe, Y. Kwak, J.H. Huh, Operation and control strategies for multi-storey double-skin facades during the heating season, Energy Build. 49 (2012) 454-465.

[22] W. Loua, M. Huanga, M. Zhangb, N. Linc, Experimental and zonal modeling for wind pressures on double-skin facades of a tall building, Energy Build. 54 (2012) 179-191.

[23] S. Malavasi, G. Messa, U. Fratino, A. Pagano, On the pressure losses through perforated plates, Flow Meas. Instrum. 28 (2012) 57-66.

[24] Y. Bayazit, E.M. Sparrow, D.D. Joseph, Perforated plates for fluid management: plate geometry effects and flow regimes, Int. J. Therm. Sci. 85 (2014) 104-111. 
[25] S. Huang, T. Mac, D. Wang, Z. Lin, Study on discharge coefficient of perforated orifices as a new kind of flowmeter, Exp. Therm. Fluid Sci. 46 (2013) 74-83.

[26] T. İnan, T. Bașaran, M.A. Ezan, Experimental and numerical investigation of natural convection in a double skin facade, Appl. Therm. Eng. 106 (2016) 1225-1235.

[27] J.P. Holman, Experimental Methods for Engineers, eighth edition, McGraw-Hill, 2011.
[28] A. Tokuç, T. Başaran, S.C. Yesügey, An experimental and numerical investigation on the use of phase change materials in building elements: the case of a flat roof in Istanbul, Energy Build. 102 (2015) 91-104.

[29] L.J. Weber, M.P. Cherian, M.E. Allen, M. Muste, Headloss Characteristics for Perforated Plates and Flat Bar Screens. Technical Report, Iowa Institute of Hydraulic Engineering, College of Engineering, University of Iowa, Iowa City, USA, 2000, Mar Report no. 411. 